\title{
Allelopathic activity of Ceratophyllum demersum L. and Najas marina ssp. intermedia (Wolfgang) Casper
}

\author{
Elisabeth M. Gross, Daniela Erhard \& Enikö Iványi \\ Limnological Institute, University of Konstanz, PO Box M659, 78457 Konstanz, Germany \\ E-mail: Elisabeth.Gross@uni-konstanz.de
}

Key words: allelochemical, allelopathy, aquatic angiosperm, cyanobacteria, exudation, submersed macrophyte

\begin{abstract}
We investigated the allelopathic activity of two submersed macrophytes with different growth forms and nutrient uptake modes, Ceratophyllum demersum and Najas marina ssp. intermedia. A bioassay-directed method development revealed optimal extraction solvents for allelochemicals from both macrophytes. For Najas, 50\% methanol and for Ceratophyllum 50\% acetone yielded the strongest inhibition in the agar-diffusion assay with various filamentous or chroococcal cyanobacteria as target species. Further fractionation by liquid-liquid extraction (LLE) and solid phase extraction (SPE) procedures showed that both aquatic plants appear to have more than one active fraction, one being hydrophilic and one moderately lipophilic. The water-soluble allelochemicals may inhibit phytoplankton whereas the lipophilic allelochemicals may act through direct cell-cell contact, e.g., against epiphytes. Both macrophytes also exuded allelopathically active compounds into the surrounding medium as shown by SPE of their incubation water.
\end{abstract}

\section{Introduction}

Allelopathy may be an adaptive strategy of submersed macrophytes in their competition for light and carbon with epiphytes and phytoplankton (Gopal \& Goel, 1993; Gross, 1999). Especially in shallow lakes, allelopathy might, besides many other abiotic and biotic factors, stabilize aquatic plant dominance over phytoplankton (Scheffer et al., 1993). Light is the most limiting factor for submersed macrophytes; especially dense epiphyte cover can considerably attenuate light intensity (Sand-Jensen, 1990) and cause carbon limitation (Madsen \& Sand-Jensen, 1994). Competition for nutrients is generally less important, because most aquatic angiosperms are rooted and obtain the majority of their macronutrients from the sediment (Carignan \& Kalff, 1980).

Ceratophyllum demersum L., however, attaches only with rhizoids to the sediment and nutrient uptake occurs primarily over the shoots (Denny, 1987). Therefore, competition with phytoplankton for nutrients takes place. $C$. demersum may grow in water depths of $0.5-8.5 \mathrm{~m}$, often inhabiting deeper water where only $1 \%$ of the surface illumination is available (Hutchinson, 1975), facilitated by a low light compensation point (Spencer \& Wetzel, 1993). Recently, Mjelde \& Faafeng (1997) showed that C. demersum hampered phytoplankton development in shallow lakes with high phosphorus load but low nitrogen. Remarkably, Fitzgerald (1969) observed that Ceratophyllum and some other macrophytes or macroalgae had low epiphyte densities under nitrogen, but not under phosphorus limitation. He did not exclude allelopathic interference. Metabolic excretions of $C$. demersum inhibited the growth of several nitrogen-fixing cyanobacteria (Kogan \& Chinnova, 1972), but this study did not rigorously rule out nutrient interference. Wium-Andersen et al. (1983) suggested elemental sulphur or a labile sulphur compound as allelopathically active substance(s). Both exuded allelochemicals and compounds extracted from $C$. demersum inhibited cyanobacteria (Jasser, 1994, 1995; Körner \& Nicklisch, 2002).

So far, allelopathy has never been associated with Najas marina. This macrophyte was rather subjected to allelopathic activity by other submersed macro- 
phytes (Agami \& Waisel, 1985). Only N. guadalupensis exhibited allelopathical activity against some aquatic plants (Elakovich, 1989; Elakovich \& Wooten, 1989). Najas marina ssp. intermedia is one of the dominant submersed macrophytes in the Lower Basin of Lake Constance, occurring at a depth of 2-3 m and forming stands of $10-50 \mathrm{~cm}$ height; thus they never reach the water surface. Like $C$. demersum, $N$. marina is also adapted to submersed life with a low light compensation point (Agami et al., 1980).

Our objectives in this study were (i) to improve extraction methods for allelopathically active compounds in C. demersum and N. marina, (ii) to investigate some chemical characteristics of the allelochemicals and (iii) to demonstrate that active compounds are released by intact macrophytes into the water.

\section{Materials and methods}

\section{Macrophytes}

Ceratophyllum demersum was sampled in three shallow eutrophic lakes in Upper Swabia, Southern Germany: Karsee (KS), Lengenweiler See (LS) and Rohrsee (RS). More details on these lakes can be found under http://www.seenprogramm.de/ or Herz (2001) and in Gross et al. (this Volume). Najas marina ssp. intermedia was collected by snorkeling in summer 1998 and 1999 in mesotrophic Lower Lake Constance, near the island of Reichenau. Plant material was washed free of debris, shock frozen in liquid nitrogen and freeze-dried. Lyophilized material was finely ground and stored in air-tight containers at room temperature in the dark until use. Fresh plant material was used for exudation experiments (see below).

\section{Target organisms}

We used three axenic strains, the filamentous cyanobacteria Anabaena sp. PCC 7120 (=SAG 25.82) and A. variabilis strain P9 (=ATCC 29413), as well as the chroococcal Synechococcus elongatus SAG 89.79. These cultures were from a long-term culture held at the institute. Additionally, fresh cultures of the SAG strains were directly received from SAG/Sammlung von Algenkulturen, Göttingen, Germany. All target organisms were cultured in a modified cyanobacteria medium (Jüttner et al., 1983), using $150 \mathrm{mg}^{-1}$ TES as buffer. Liquid batch cultures were kept on a shaker
(115 rpm) at $24{ }^{\circ} \mathrm{C}, 50 \mu \mathrm{mol}$ photons PAR $\mathrm{m}^{-2} \mathrm{~s}^{-1}$ and a photoperiod of L:D 13:11.

\section{Extraction}

Plant material was extracted twice with solvent $(1 \mathrm{ml}$ per $10 \mathrm{mg}$ plant dry mass [dm]) for $2 \mathrm{~h}$ each with constant stirring. As solvents, we used water, as well as methanol or acetone either pure or in defined mixtures with water $(\mathrm{v} / \mathrm{v})$. Ultrapure water (USF Elga HPLC system) was used throughout for the chemical analysis. For N. marina, we used water, 25, 50, 70, 100\% methanol, or $70 \%$ acetone as extraction solvents. $C$. demersum was extracted with 50, 70, 100\% methanol, 50 or $70 \%$ acetone. Each extraction method was replicated at least once. Aliquots of these crude extracts were evaporated to dryness and resuspended in 50\% methanol in a final concentration equivalent to $100 \mathrm{mg}$ extracted $\mathrm{dm} \mathrm{ml}^{-1}$.

\section{Fractionation of crude extracts}

To fractionate crude extracts depending on polarity, we performed high performance liquid chromatography (HPLC), liquid-liquid extraction (LLE) and solid phase extractions (SPE). SPE was performed with both plants, only extracts of $N$. marina were fractionated by HPLC and LLE. HPLC separations were carried out on a LiChrospher-100 column (RP18 endc., $250 \times 4 \mathrm{~mm}, 5 \mu \mathrm{m}$ particle size; Knauer, Germany) with a flow rate of $1 \mathrm{ml} \mathrm{min}^{-1}$ on a Jasco HPLC system and a linear gradient with solvent $\mathrm{A}$ : water and solvent B: methanol (0-20 min from $1 \%$ to $100 \% \mathrm{~B}$, thereafter $15 \min 100 \% \mathrm{~B}$ ). Extracts equivalent to 4 or $5 \mathrm{mg} \mathrm{dm}$ were injected and single fractions of 5 $\mathrm{ml}$ were collected. They were evaporated to dryness, redissolved in 50\% methanol and subsequently tested in our bioassay (see below).

For LLE and SPE, methanol was evaporated from the aliquots, yielding aqueous extracts. In the LLE, the resulting aqueous aliquot of the crude extract was diluted to $7.5 \mathrm{ml}$ with water and twice partitioned with each $5 \mathrm{ml}$ diethylether. Ether phases were combined and dried over anhydrous $\mathrm{Na}_{2} \mathrm{SO}_{4}$. Both the water and the ether phase were concentrated to dryness and resuspended in 50\% methanol as described above. For SPE, an aqueous aliquot of the crude extract was passed over a preconditioned SPE-C18 cartridge (Varian Bond Elut, $3 \mathrm{cc}, 500 \mathrm{mg}$ sorbens). Afterwards, the cartridge was washed with one reservoir volume of water and then stepwise eluted with each 
three reservoir volumes of 10, 25, 50, 70 and $100 \%$ methanol. This yielded six fractions in total, fraction 1 being the non-retained aqueous eluent. SPE with Najas was performed with aliquots of two different crude extracts, those using 25 and 50\% methanol as extraction solvents. With $C$. demersum, we used only the 50\% acetone extract. SPE was modified (method SPE2) once for $C$. demersum in that an aliquot of the crude extract was evaporated and redissolved in 10\% methanol. This extract was applied to the C18 cartridge and eluted with $25-100 \%$ methanol as described above, yielding only five fractions in total.

\section{Heat stability of allelochemicals}

Aqueous aliquots of crude extracts from Najas were boiled in a water bath for $1 \mathrm{~h}$. Then the extract was evaporated to dryness and resuspended in 50\% methanol as described above.

\section{Exudation}

Lipophilic, allelopathically active compounds exuded by the macrophytes into the surrounding water were extracted with SPE. Fresh plants were submersed in tap water for 3, 4 or $24 \mathrm{~h}$. Controls were performed for the same time using the same volumes of tap water without plant addition. The incubation water was filtered successively over GF/F (Whatman) and nitrocellulose membrane filters $(0.2 \mu \mathrm{m}$ pore size, Schleicher \& Schuell) to remove suspended particles. Preconditioned SPE-C18 filters (3M Empore disks, $47 \mathrm{~mm} \varnothing$ ) were used to adsorb exuded compounds. The incubation water was passed over the SPE-filter under low vacuum ( -200 to -400 mbar). The filter was then washed with a small volume of ultrapure water and vacuum dried for $1 \mathrm{~min}$. Afterwards, the adsorbed compounds were eluted with $30 \mathrm{ml}$ methanol. This lipophilic eluate was evaporated to dryness and redissolved in a defined volume of 50\% methanol.

\section{Bioassays}

The activity of extracted or exuded compounds was tested in the agar diffusion assay (ADA) as our standard bioassay system. The ADA was performed as described previously (Flores \& Wolk, 1986; Gross et al., 1991) using inoculation densities of $0.04 \mathrm{OD}_{530} \mathrm{~nm}$ (optical density of culture at $530 \mathrm{~nm}$ ) for Anabaena spp. and 0.1 OD $530 \mathrm{~nm}$ for Synechococcus. Agar plates were incubated for 5-7 days at $28{ }^{\circ} \mathrm{C}$ and a constant illumination of $80 \mu \mathrm{mol}$ photons PAR $\mathrm{m}^{-2}$ $\mathrm{s}^{-1}$. Extracts were generally applied in amounts equivalent to $0.5,1$ and $2 \mathrm{mg}$ of extracted $\mathrm{dm}$. SPE-enriched exudates were used in amounts up to $10 \mathrm{~g}$ plant fresh mass $(\mathrm{fm})$ per test. Active fractions caused clearing areas in the algal overlayer.

\section{Results}

\section{Allelopathic activity of plant extracts}

Extracts of Ceratophyllum demersum inhibited both Anabaena PCC 7120 and Synechococcus elongatus at all tested concentrations and with all solvent mixtures used (Table 1). A. variabilis $\mathrm{P} 9$ was less sensitive. In general, clearing areas in the agar diffusion assay increased with extract concentration. Extracts differed somewhat in their allelopathic activity depending on the origin of the plant material. The largest inhibition was observed when lyophilized plant material was extracted with $50 \%$ acetone. This solvent was subsequently used for all extractions.

Extracts of $N$. marina inhibited the growth of all target organisms, but the extent of inhibition depended on the extraction solvent and the test species used in the assay. In general, the activity of $N$. marina was weaker than that of $C$. demersum. The strongest activity against all three test strains was achieved by extracting plant tissue with 50\% methanol (Table 2). The mean diameter of the clearing zones in the ADA did not decrease after heating the extract.

\section{Fractionation of plant extracts}

SPE of $50 \%$ acetone crude extracts of $C$. demersum from all lakes exhibited variable allelopathic activity against Anabaena sp. PCC 7120 (Table 3). Using method SPE2 and A. variabilis P9, we found inhibition predominantly in fraction 2 and 5 , and only minor activity in fraction 6 (Table 3). This indicates a hydrophilic and a moderately lipophilic fraction.

HPLC directed fractionation of Najas extract revealed two active fractions in the agar diffusion assay (ADA). Clearing zones were caused by fraction 1 (0-5 min) and fraction $5(20-25 \mathrm{~min})$ against Anabaena sp. PCC 7120 (data not shown). These fractions eluted with 1-26\% methanol and $100 \%$ methanol, respectively, indicating that hydrophilic and lipophilic substances are allelopathically active. After LLE, application of the organic phase equivalent to at least 
Table 1. Effect of different solvents on inhibitory activity of extracts from Ceratophyllum demersum. Extracts were applied in concentrations equivalent to $0.5,1$ or $2 \mathrm{mg} \mathrm{dm}$. Extracts from macrophytes from different lakes (Karsee, KS; Lengenweiler See, LS; and Rohrsee, RS) were tested against three target species. Data represent mean area of clearing zones $\left(\mathrm{mm}^{2}\right)$ of two to five replicates each. - No tests performed

\begin{tabular}{|c|c|c|c|c|c|c|c|c|c|}
\hline \multirow[t]{2}{*}{ Solvent } & \multirow[t]{2}{*}{$\begin{array}{l}\text { Plant } \\
\text { dm }\end{array}$} & \multicolumn{3}{|c|}{$\begin{array}{l}\text { Anabaena sp. } \\
\text { PCC } 7120\end{array}$} & \multicolumn{2}{|c|}{$\begin{array}{l}\text { Synechococcus } \\
\text { elongatus SAG } 89.79\end{array}$} & \multicolumn{3}{|c|}{$\begin{array}{l}\text { Anabaena } \\
\text { variabilis } \mathrm{P} 9\end{array}$} \\
\hline & & RS & $\mathrm{KS}$ & LS & RS & $\mathrm{LS}$ & $\mathrm{RS}$ & $\mathrm{KS}$ & LS \\
\hline \multirow[t]{3}{*}{$50 \% \mathrm{MeOH}$} & 0.5 & 78.5 & - & 63.6 & 50.3 & 153.9 & - & - & - \\
\hline & 1 & 236.0 & - & 122.7 & 153.9 & 346.4 & - & - & - \\
\hline & 2 & 240.5 & - & 113.1 & 415.5 & 615.8 & - & - & - \\
\hline \multirow[t]{3}{*}{$70 \% \mathrm{MeOH}$} & 0.5 & 95.0 & - & 70.9 & 122.7 & 78.5 & - & - & 0 \\
\hline & 1 & 132.7 & - & 132.7 & 132.7 & 176.7 & - & - & 330.0 \\
\hline & 2 & 100.9 & - & 227.0 & 201.1 & 213.8 & - & - & 530.9 \\
\hline \multirow[t]{3}{*}{$100 \% \mathrm{MeOH}$} & 0.5 & 50.3 & - & 44.2 & 63.6 & 103.9 & - & - & - \\
\hline & 1 & 86.6 & - & 103.9 & 132.7 & 83.9 & - & - & - \\
\hline & 2 & 218.2 & - & 165.1 & 139.6 & 213.8 & - & - & - \\
\hline \multirow[t]{3}{*}{$50 \%$ Acetone } & 0.5 & 68.4 & 50.3 & 38.0 & 113.1 & 63.6 & 0 & 0 & 0 \\
\hline & 1 & 132.7 & 110.0 & 89.0 & 139.6 & 122.7 & 19.6 & 12.6 & 19.6 \\
\hline & 2 & 283.5 & 201.1 & 201.1 & 227.0 & 227.0 & 33.3 & 28.3 & 38.5 \\
\hline \multirow[t]{3}{*}{$70 \%$ Acetone } & 0.5 & 86.6 & - & 63.6 & 95.0 & 78.5 & - & - & 0 \\
\hline & 1 & 188.7 & - & 113.1 & 213.8 & 227.0 & - & - & 153.9 \\
\hline & 2 & 201.1 & - & 161.4 & 314.2 & 380.1 & - & - & 201.1 \\
\hline
\end{tabular}

$2 \mathrm{mg} \mathrm{dm}$ caused clearing zones whereas the aqueous phase was already active when 0.5 or $1 \mathrm{mg} \mathrm{dm}$ was used. Fractionation of the LLE aqueous phase by HPLC yielded two active fractions. The first eluted at $0-5$ min with $1-26 \%$ methanol and the second between 20 and 25 min with $100 \%$ methanol. Similar results were gained by SPE fractionation of crude extracts. Here, the aqueous eluent and fraction 5 (elution with $75 \%$ methanol) showed inhibition in the ADA against Anabaena sp. PCC 7120 (data not shown).

\section{Exudation of allelochemicals}

After $24 \mathrm{~h}$ incubation of $C$. demersum in water, SPEenriched exudates from LS and RS caused clearing zones when applied in concentrations equivalent to 2$5 \mathrm{~g}$ of fresh mass (Table 4). Exudate of RS material exhibited already a weak inhibition after $4 \mathrm{~h}$ of incubation. SPE-enriched exudates of $C$. demersum from KS did not inhibit Anabaena PCC 7120.

SPE-enriched exudates of $N$. marina caused clearing zones of 133 and $254 \mathrm{~mm}^{2}$, respectively, when plants with 6.2 or $8.2 \mathrm{~g} \mathrm{fm}$ were incubated for $3 \mathrm{~h}$ in $400 \mathrm{ml}$ of tap water. Samples with $4-5 \mathrm{~g}$ fm incubated for $24 \mathrm{~h}$ showed a stronger activity. Controls with the same volume of tap water but without plants were inactive.

\section{Discussion}

Our experiments show that two macrophytes with different growth architecture, Ceratophyllum demersum and Najas marina ssp. intermedia, produce and release allelopathically active compounds. It is the first time that allelopathic activity has been demonstrated for $N$. marina.

We optimized the extraction procedure of active compounds from freeze-dried material. Based on the solvents used for extraction and fractionation and the results of the bioassays, both macrophytes contain two active fractions, one more hydrophilic, one moderately lipophilic. Although the precise nature of the active compounds is still unknown, we assume that hydro- 
Table 2. Effect of different extraction solvents on allelopathic activity of Najas marina from Lake Constance. Extracts were applied in concentrations equivalent to $0.5,1$ or $2 \mathrm{mg} \mathrm{dm}$ and were tested against three target species. Plant material collected in 1999 was extracted in 2000 and again with additional solvents in 2001. Data represent mean area of clearing zones $\left(\mathrm{mm}^{2}\right)$ of two to five replicates each. - No tests performed. + weak inhibition. ${ }^{*}$ Clearing zones with inner and outer clearing ring $(x / y)$; in between $2 \mathrm{~mm}$ zone of algal growth

\begin{tabular}{|c|c|c|c|c|c|c|c|}
\hline \multirow[t]{2}{*}{ Solvent } & \multirow{2}{*}{$\begin{array}{l}\text { Plant } \\
\mathrm{dm}\end{array}$} & \multicolumn{3}{|l|}{2000} & \multicolumn{3}{|l|}{2001} \\
\hline & & $\begin{array}{l}\text { Anabaena } \\
\text { variabilis } \\
\text { P9 }\end{array}$ & $\begin{array}{l}\text { Anabaena } \\
\text { sp. PCC } \\
7120\end{array}$ & $\begin{array}{l}\text { Synechococcus } \\
\text { elongatus } \\
\text { SAG } 89.79\end{array}$ & $\begin{array}{l}\text { Anabaena } \\
\text { variabilis } \\
\text { P9 }\end{array}$ & $\begin{array}{l}\text { Anabaena } \\
\text { sp. PCC } \\
7120\end{array}$ & $\begin{array}{l}\text { Synechococcus } \\
\text { elongatus } \\
\text { SAG } 89.79\end{array}$ \\
\hline \multirow[t]{3}{*}{$\mathrm{H}_{2} \mathrm{O}$} & 0.5 & 0 & 5.1 & 0 & - & - & - \\
\hline & 1 & 0 & 6.3 & 0 & - & - & - \\
\hline & 2 & 0 & 38.5 & 0 & - & - & - \\
\hline \multirow[t]{3}{*}{$25 \% \mathrm{MeOH}$} & 0.5 & - & - & - & 50.3 & 0 & 0 \\
\hline & 1 & - & - & - & 63.6 & 0 & 0 \\
\hline & 2 & - & - & - & 78.5 & 0 & 0 \\
\hline \multirow[t]{3}{*}{$50 \% \mathrm{MeOH}$} & 0.5 & 0 & 74.2 & 38.5 & $12.6 / 176.7^{*}$ & 0 & 24.6 \\
\hline & 1 & 0 & 154.4 & 72.7 & $50.3 / 314.2^{*}$ & 0 & 83.3 \\
\hline & 2 & 31.5 & 142.9 & 122.9 & $78.5 / 388.1^{*}$ & 66.5 & 113.1 \\
\hline \multirow[t]{3}{*}{$75 \% \mathrm{MeOH}$} & 0.5 & 0 & 35.0 & 46.0 & - & - & - \\
\hline & 1 & 0 & 94.6 & 122.9 & - & - & - \\
\hline & 2 & 0 & 72.3 & 315.0 & - & - & - \\
\hline \multirow[t]{3}{*}{$100 \% \mathrm{MeOH}$} & 0.5 & 0 & + & 19.6 & - & - & - \\
\hline & 1 & 0 & 10 & 78.5 & - & - & - \\
\hline & 2 & 0 & 95.1 & 95.8 & - & - & - \\
\hline \multirow[t]{3}{*}{$70 \%$ Acetone } & 0.5 & - & - & - & 0 & 0 & 0 \\
\hline & 1 & - & - & - & 0 & 0 & 28.3 \\
\hline & 2 & - & - & - & 0 & 0 & 52.8 \\
\hline
\end{tabular}

philic compounds are more easily released into the water whereas lipophilic compounds may act primarily on the plant surface via direct contact, e.g., against epiphytes. Allelochemicals in Najas are heat stable. For C. demersum, our results indicate that other, yet unknown, allelopathically active compounds are present. Elemental sulphur or other labile sulphur compounds have been extracted with the highly lipophilic petroleum from $C$. demersum (Wium-Andersen et al., 1983). It is unlikely that those compounds are present in our extracts. In earlier works, aqueous extracts of C. demersum caused a decline of cyanobacteria and an increase of chlorophytes in growth assays with natural phytoplankton (Jasser, 1995). Using dialysis membranes, $C$. demersum was shown to specifically affect cyanobacteria (Jasser, 1995), probably through interference with optimal functioning of photosystem II (Körner \& Nicklisch, 2002).

Inhibitory effects of plant extracts against test organisms demonstrate an allelopathic potential, but they can not prove allelopathy in situ. Although many allelochemicals have been isolated from aquatic plants, often their release, i.e. by exudation or leaching, into the surrounding medium was not proven, thus the ecological relevance of these studies remains questionable. Exudation of allelochemicals has been shown for Myriophyllum spicatum (Gross et al., 1996; Nakai et al., 1999). We could show that yet unidentified, slightly lipophilic compounds that could be trapped by SPE, are released into the incubation water by intact $C$. demersum and $N$. marina. Although $N$. marina is well adapted to low irradiance (Agami 
Table 3. Allelopathic activity of SPE-fractionated crude extracts of Ceratophyllum demersum from different lakes (Karsee, KS; Lengenweiler See, LS; and Rohrsee, RS) in Upper Swabia. Concentrations used in the agar diffusion assay were equivalent to 1,2 or $5 \mathrm{mg} \mathrm{dm}$ of plant material. Data represent mean area of clearing zones $\left(\mathrm{mm}^{2}\right)$ of three replicates each. - not tested. + weak inhibition. Numbers in brackets: diffuse clearing zone

\begin{tabular}{|c|c|c|c|c|c|c|c|}
\hline \multirow[t]{2}{*}{ SPE fraction } & \multirow[t]{2}{*}{$\mathrm{mg} \mathrm{dm}$} & \multicolumn{3}{|c|}{ Anabaena sp. PCC 7120} & \multicolumn{3}{|c|}{ Anabaena variabilis $\mathrm{P9}$} \\
\hline & & KS & $\mathrm{LS}$ & RS & $\mathrm{KS}$ & LS & RS \\
\hline \multirow[t]{3}{*}{$1-\mathrm{H}_{2} \mathrm{O}$} & 1 & 0 & 0 & 0 & - & - & - \\
\hline & 2 & 0 & 0 & 0 & - & - & - \\
\hline & 5 & 0 & 0 & 0 & - & - & - \\
\hline \multirow[t]{3}{*}{$2-10 \% \mathrm{MeOH}$} & 1 & 0 & 0 & 0 & + & 50.3 & + \\
\hline & 2 & 0 & 0 & 0 & 50.3 & 283.5 & 50.3 \\
\hline & 5 & 28.3 & 0 & 0 & 452.4 & 452.4 & 254.5 \\
\hline \multirow[t]{3}{*}{$3-25 \% \mathrm{MeOH}$} & 1 & 0 & + & 0 & 0 & 0 & 0 \\
\hline & 2 & 16.1 & + & 0 & 0 & 0 & 0 \\
\hline & 5 & 113.1 & + & 0 & 0 & 0 & 0 \\
\hline \multirow[t]{3}{*}{$4-50 \% \mathrm{MeOH}$} & 1 & 0 & 0 & 0 & 0 & 0 & 0 \\
\hline & 2 & 0 & 0 & 0 & 0 & 0 & 0 \\
\hline & 5 & 50.3 & 0 & 0 & 0 & 0 & 0 \\
\hline \multirow[t]{3}{*}{$5-75 \% \mathrm{MeOH}$} & 1 & 3.1 & 0 & 0 & 0 & 7.1 & 0 \\
\hline & 2 & 12.6 & 0 & 0 & 7.1 & 38.5 & 0 \\
\hline & 5 & 71.1 & 0 & + & 38.5 & 68.6 & 3.1 \\
\hline \multirow[t]{3}{*}{$6-100 \% \mathrm{MeOH}$} & 1 & 19.6 & + & 12.6 & + & + & + \\
\hline & 2 & 28.3 & + & 132.7 & + & 7.1 & + \\
\hline & 5 & 63.6 & + & 314.2 & (12.6) & (12.6) & $(38.5)$ \\
\hline
\end{tabular}

et al., 1980), apparently at least $250 \mu \mathrm{mol}$ photons PAR $\mathrm{m}^{-2} \mathrm{~s}^{-1}$ incident light is necessary for the production of seeds in this species (Agami et al., 1984). Thus, growth suppression of shading organisms such as epiphytes and phytoplankton due to exudation of allelopathically active substances might be important for optimal growth and reproduction in N. marina. Allelopathy thus may play an important role for both plants in their natural habitat. The suppression of primary producers like cyanobacteria can increase the competitiveness of submersed macrophytes.

If allelopathy is able to increase the strength of macrophyte communities and to support their stability, one can also assume that allelopathic interactions might influence indirectly the composition of the whole littoral community (Gopal \& Goel, 1993). Submersed macrophytes are not only important primary producers but they also greatly increase colonization area for other organisms, provide substrate for spawn and refuge for juvenile fish or zooplankton. Dense macrophyte stands decrease flow velocity and water turbulence, thereby preventing resuspension of sediment and increasing sedimentation rate. As a result, macrophytes increase water quality and due to feedback regulation, growth of phytoplankton and epiphytes is reduced whereas the macrophyte community is stabilised (Scheffer et al., 1993). Allelopathy might well be a regulating factor for stable macrophyte communities as proposed in the model of alternating stable states of shallow eutrophic lakes (Scheffer et al., 1993).

Our results demonstrate that allelopathy might be a widespread adaptive trait of submersed macrophytes in their competition with epiphytes and phytoplankton. Further studies are needed to identify the active compounds, and investigate the conditions under which optimal release in situ may occur. 
Table 4. Allelopathic activity of SPE-enriched incubation water of Ceratophyllum demersum from different lakes in Upper Swabia (Lengenweiler See, LS; and Rohrsee, RS). Incubation time was 4 or $24 \mathrm{~h}$. Concentrations were used equivalent to 1,2 or $5 \mathrm{~g} \mathrm{fm}$ of plant material used for exudation. Data represent mean area of clearing zones $\left(\mathrm{mm}^{2}\right)$ of two replicates each. Values in brackets: only diffuse clearing zone visible

\begin{tabular}{cccccc}
\hline \multirow{2}{*}{$\mathrm{gfm}$} & $\mathrm{LS}$ & & & $\mathrm{RS}$ & \\
\cline { 2 - 3 } \cline { 5 - 6 } & $4 \mathrm{~h}$ & $24 \mathrm{~h}$ & & $\mathrm{~h}$ & $24 \mathrm{~h}$ \\
\hline 0 & 0 & 0 & 0 & 0 \\
1 & 0 & 0 & 0 & 0 \\
2 & 0 & 113.1 & & $(28.3)$ & 0 \\
5 & 0 & 283.5 & & $(38.5)$ & 123.0 \\
\hline
\end{tabular}

\section{Acknowledgements}

We gratefully acknowledge the help of Claudia Feldbaum with extractions and bioassays. The manuscript benefited from helpful reviews by László Gy. Szabó and an anonymous reviewer. This work was supported by DFG (SFB 454, A2 and the EU (EVK1-CT-199900039 ECOFRAME), both to E.M.G.

\section{References}

Agami, M., S. Beer \& Y. Waisel, 1980. Growth and photosynthesis of Najas marina L. as affected by light intensity. Aquat. Bot. 9: 285-289.

Agami, M., S. Beer \& Y. Waisel, 1984. Seasonal variations in the growth capacity of Najas marina L. as a function of various water depth at the Yarkon Springs, Israel. Aquat. Bot. 19: 45-51.

Agami, M. \& Y. Waisel, 1985. Inter-relationship between $\mathrm{Na}$ jas marina L. and three other species of aquatic macrophytes. Hydrobiologia 126: 169-173.

Carignan, R. \& J. Kalff, 1980. Phosphorus sources for aquatic weeds: water or sediments? Science 207: 987-989.

Denny, P., 1987. Mineral cycling by wetland plants - a review. Arch. Hydrobiol. Beih. Ergebn. Limnol. 27: 1-25.

Elakovich, S. D., 1989. Allelopathic aquatic plants for aquatic weed management. Biologia Plantarum 31: 479-486.

Elakovich, S. D. \& J. W. Wooten, 1989. Allelopathic potential of 16 aquatic and wetland plants. J. Aquat. Plant Manag. 27: 78-84.

Fitzgerald, G. P., 1969. Some factors in the competition or antagonism among bacteria, algae and aquatic weeds. J. Phycol. 5: 351-359.
Flores, E. \& C. P. Wolk, 1986. Production, by filamentous, nitrogenfixing cyanobacteria, of a bacteriocin and of other antibiotics that kill related strains. Arch. Microbiol. 145: 215-219.

Gopal, B. \& U. Goel, 1993. Competition and allelopathy in aquatic plant communities. Bot. Rev. 59: 155-210.

Gross, E. M., 1999. Allelopathy in benthic and littoral areas: Case studies on allelochemicals from benthic cyanobacteria and submersed macrophytes. In Inderjit, K. M., M. Dakshini \& C. L. Foy (eds), Principles and Practices in Plant Ecology: Allelochemical Interactions. CRC Press, LLC, Boca Raton: 179-199.

Gross, E. M., H. Meyer \& G. Schilling, 1996. Release and ecological impact of algicidal hydrolyzable polyphenols in Myriophyllum spicatum. Phytochemistry 41: 133-138.

Gross, E. M., C. P. Wolk \& F. Jüttner, 1991. Fischerellin, a new allelochemical from the freshwater cyanobacterium Fischerella muscicola. J. Phycol. 27: 686-692.

Gross, E. M., C. Feldbaum \& A. Graf, 2003. Epiphyte biomass and elemental composition on submersed macrophytes in shallow eutrophic lakes. Hydrobiologia 506-509: 559-565.

Herz, G., 2001. Aktionsprogramm zur Sanierung oberschwäbischer Weiher und Seen. Report. Tettnang/Tübingen, Germany.

Hutchinson, G. E., 1975. A Treatise on Limnology. Vol III. Limnological Botany. John Wiley \& Sons, New York.

Jasser, I., 1994. Influence of Ceratophyllum demersum on phytoplankton community in experimental conditions. Verh. int. Ver. theor. angew. Limnol. 25: 2291-2295.

Jasser, I., 1995. The influence of macrophytes on a phytoplankton community in experimental conditions. Hydrobiologia 306: $21-$ 32.

Jüttner, F., J. Leonhardt \& S. Möhren, 1983. Environmental factors affecting the formation of mesityloxide, dimethylallylic alcohol and other volatile compounds excreted by Anabaena cylindrica. J. Gen. Microbiol. 129: 407-412.

Kogan, S. I. \& G. A. Chinnova, 1972. Relations between Ceratophyllum demersum (L.) and some blue-green algae. Hydrobiol. J. 8: 14-19 (21-27).

Körner, S. \& A. Nicklisch, 2002. Allelopathic growth inhibition of selected phytoplankton species by submerged macrophytes. J. Phycol. 38: 862-871.

Madsen, T. V. \& K. Sand-Jensen, 1994. The interactive effects of light and inorganic carbon on aquatic plant growth. Plant Cell Environ. 17: 955-962.

Mjelde, M. \& B. A. Faafeng, 1997. Ceratophyllum demersum hampers phytoplankton development in some small Norwegian lakes over a wide range of phosphorus concentrations and geographical latitude. Freshwat. Biol. 37: 355-365.

Nakai, S., Y. Inoue, M. Hosomi \& A. Murakami, 1999. Growth inhibition of blue-green algae by allelopathic effects of macrophytes. Wat. Sci. Technol. 39: 47-53.

Sand-Jensen, K., 1990. Epiphyte shading - its role in resulting depth distribution of submerged aquatic macrophytes. Folia Geobotanica \& Phytotaxonomica 25: 315-320.

Scheffer, M., S. H. Hosper, M. L. Meijer, B. Moss \& E. Jeppesen, 1993. Alternative equilibria in shallow lakes. Trends Ecol. Evol. 8: 275-279.

Spencer, W. E. \& R. G. Wetzel, 1993. Acclimation of photosynthesis and dark respiration of a submersed angiosperm beneath ice in a temperate lake. Plant Physiol. 101: 985-991.

Wium-Andersen, S., U. Anthoni \& G. Houen, 1983. Elemental sulphur, a possible allelopathic compound from Ceratophyllum demersum. Phytochemistry 22: 2613. 